Geosci. Model Dev. Discuss., 4, 1185-1211, 2011 www.geosci-model-dev-discuss.net/4/1185/2011/ doi:10.5194/gmdd-4-1185-2011

(c) Author(s) 2011. CC Attribution 3.0 License.

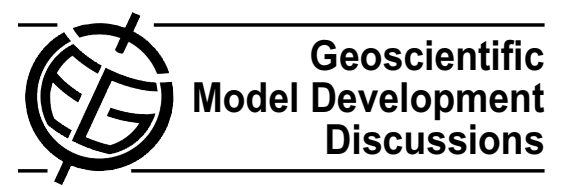

GMDD

$4,1185-1211,2011$

CO as a tracer in CLaMS

Development (GMD). Please refer to the corresponding final paper in GMD if available.

\title{
Carbon monoxide as a tracer for tropical troposphere to stratosphere transport in the Chemical Lagrangian Model of the Stratosphere (CLaMS)
}

R. Pommrich ${ }^{1,4,5}$, R. Müller ${ }^{1}$, J.-U. Grooß ${ }^{1}$, P. Konopka ${ }^{1}$, G. Günther ${ }^{1}$, H.-C. Pumphrey ${ }^{2}$, S. Viciani ${ }^{3}$, F. D'Amato ${ }^{3}$, and M. Riese ${ }^{1}$

${ }^{1}$ IEK-7, Forschungszentrum Jülich, Jülich, Germany

${ }^{2}$ School of GeoSciences, University of Edinburgh, Edinburgh, UK

${ }^{3}$ CNR-Istituto Nazionale di Ottica (CNR-INO), L. go E. Fermi 6, 50125 Firenze, Italy

${ }^{4}$ Laboratoire d'Aérologie, UMR5560, CNRS/INSU-Université de Toulouse 3 ,

14 Av Edouard Belin, 31400 Toulouse, France

${ }^{5}$ Groupe d'étude de l'Atmosphère Météorologique, URA 1357, CNRM-GAME, Météo-France, 42 Av Gaspard Coriolis, 31057 Toulouse Cedex 1, France

Received: 12 May 2011 - Accepted: 17 May 2011 - Published: 14 June 2011

Correspondence to: R. Pommrich (robert.pommrich@meteo.fr)

Published by Copernicus Publications on behalf of the European Geosciences Union.

\section{R. Pommrich et al.}
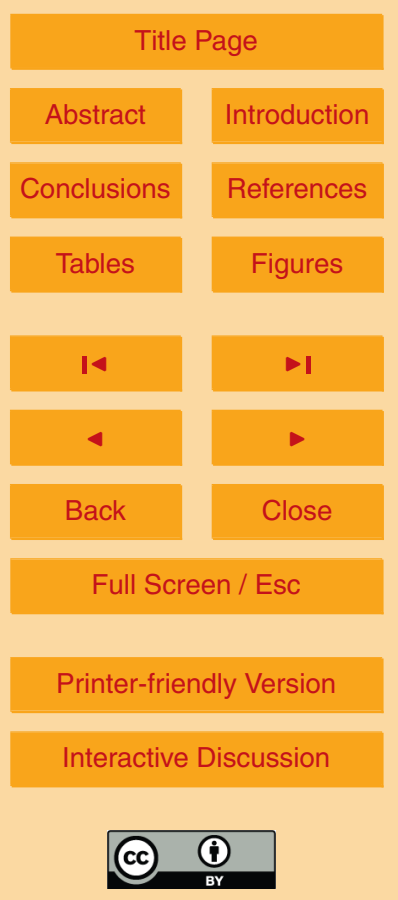


\section{Abstract}

Variations in the mixing ratio of trace gases of tropospheric origin entering the stratosphere in the tropics are of interest for assessing both troposphere to stratosphere transport fluxes in the tropics and the impact on the composition of the tropical lower

5 stratosphere of quasi-horizontal in-mixing into the tropical tropopause layer from the mid-latitude stratosphere. Here, we present a simplified chemistry scheme for the Chemical Lagrangian Model of the Stratosphere (CLaMS) for the simulation, at comparatively low numerical cost, of $\mathrm{CO}$, ozone, and long-lived trace substances $\left(\mathrm{CH}_{4}\right.$, $\mathrm{N}_{2} \mathrm{O}, \mathrm{CCl}_{3} \mathrm{~F}$, and $\mathrm{CO}_{2}$ ) in the lower tropical stratosphere. The boundary conditions 10 at the ground are represented for the long-lived trace substances $\mathrm{CH}_{4}, \mathrm{~N}_{2} \mathrm{O}, \mathrm{CCl}_{3} \mathrm{~F}$, and $\mathrm{CO}_{2}$ based on ground-based measurements. The boundary condition for $\mathrm{CO}$ in the free troposphere is deduced from MOPITT measurements. We find that the zonally averaged tropical $\mathrm{CO}$ anomaly patterns simulated by this model version of CLaMS are in good agreement with observations. The introduction of a new scheme in the 15 ECMWF integrated forecast system (Tompkins et al., 2007) for the ice supersaturation after September 2006, results in a somewhat less good agreement between observed and simulated $\mathrm{CO}$ patterns in the tropical lower stratosphere after this date.

\section{Introduction}

Carbon monoxide (CO) has sources at the Earth's surface mostly from incomplete combustion of fossil fuels and from biomass burning. $\mathrm{CO}$ is also chemically produced in the troposphere by the oxidation of methane and non-methane hydrocarbons and is removed from the atmosphere by oxidation with $\mathrm{OH}$, leading to a lifetime ranging between several weeks to a few months in the lower atmosphere; the life time in the stratosphere is a few months (Schoeberl et al., 2006). The CO concentration in the troposphere is further determined by transport processes. Because of its relatively long lifetime CO is useful as an indicator of long-range transport of polluted air-masses. In particular,
GMDD

4, 1185-1211, 2011

$\mathrm{CO}$ as a tracer in CLaMS

R. Pommrich et al.

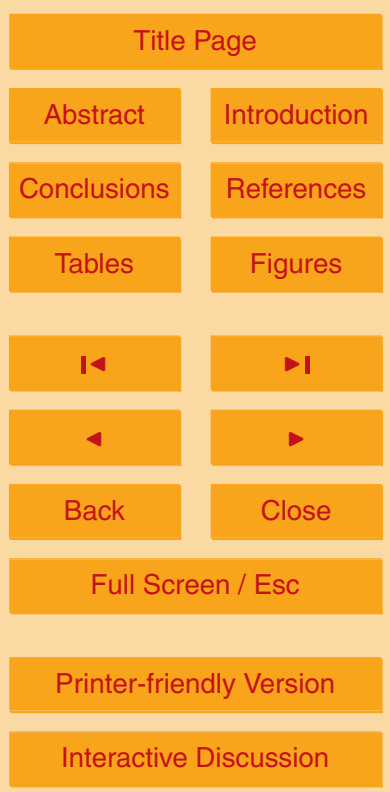

Interactive Discussion 
because of the low background mixing ratios of $\mathrm{CO}$ in the lower stratosphere, $\mathrm{CO}$ is an important tracer of troposphere to stratosphere transport, during strong convective activity (Ricaud et al., 2007), within the Asian monsoon circulation (Park et al., 2007, 2008), and during slow ascent and mixing at the bottom of the tropical tropopause layer 5 (TTL) (Konopka et al., 2007; Schoeberl et al., 2006; Fueglistaler et al., 2009; Homan et al., 2010). Moreover, it has been observed that seasonal variations in the mixing ratio of $\mathrm{CO}$ entering the stratosphere at the bottom of the TTL are carried upward with the rising air in the tropics with the signal being observable throughout the tropical lower stratosphere (Schoeberl et al., 2006; Randel et al., 2007; Liu et al., 2007), a 10 phenomenon commonly referred to as "atmospheric tape recorder" (Mote et al., 1996). Here we describe an extension of the Chemical Lagrangian Model of the Stratosphere (CLaMS) (McKenna et al., 2002b,a) that allows multi-annual simulations of CO in the tropical upper troposphere and lower stratosphere to be made for investigations of phenomena like the atmospheric tape recorder in CO. CLaMS was originally designed as a model for stratospheric polar chemical ozone loss (McKenna et al., 2002a; Grooß et al., 2002; Konopka et al., 2004; Grooß and Müller, 2007) and was recently extended to the analysis of transport processes in the tropopause region, both in the extratropics (Pan et al., 2006; Vogel et al., 2011) and in the tropics (Konopka et al., $2007,2010)$. This version of CLaMS was recently successfully applied to describe the irregular tape-recorder pattern discovered for HCN (Pumphrey et al., 2008; Pommrich et al., 2010).

The model concept used here is rather different from chemical models of the stratosphere and troposphere that employ a comprehensive description of the tropospheric chemistry and a wide range of emissions of trace substances at the ground (e.g., Jöckel et al., 2006; Garcia et al., 2007; Schultz et al., 2008; Morgenstern et al., 2009). In contrast, we make use of $\mathrm{CO}$ measurements from the Measurements Of Pollution In The Troposphere (MOPITT) satellite experiment (Deeter et al., 2003) for formulating a lower boundary condition for $\mathrm{CO}$ for multi-annual simulations of upper tropospheric and lower stratospheric transport of $\mathrm{CO}$ in the tropics. Together with boundary conditions at the

\section{GMDD}

4, 1185-1211, 2011

CO as a tracer in CLaMS

R. Pommrich et al.

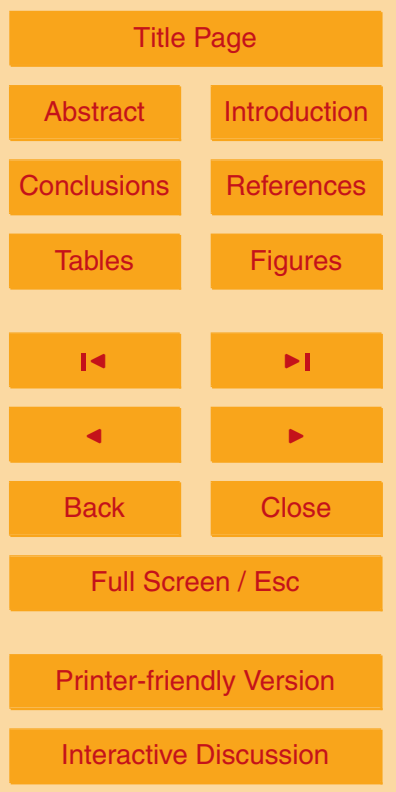


ground for the long-lived species $\mathrm{CH}_{4}, \mathrm{~N}_{2} \mathrm{O}, \mathrm{CCl}_{3} \mathrm{~F}$, and $\mathrm{CO}_{2}$ and a simplified chemistry scheme (with prescribed radical concentrations) this allows successful simulations of $\mathrm{CO}$ in the lower tropical stratosphere to be made at comparatively low numerical cost. We present simulations of CO using the CLaMS chemical transport model over the 5 time period from October 2001 to the end of 2008 for the tropical lower stratosphere and compare the results with both remote sensing and in-situ measurements. We find that this model version of CLaMS allows a successful simulation of the CO anomaly pattern in the lower tropical stratosphere.

\section{Measurements of tropical CO}

10 We use several sources for tropical $\mathrm{CO}$ data, both for prescribing boundary conditions for a multi-annual CLaMS simulation and for evaluating the results of the simulation. We use data from the MOPITT instrument, a nadir looking satellite experiment (Deeter et al., 2003), from the Microwave Limb Sounder (MLS), a microwave limb viewing instrument (Waters et al., 2006) and in-situ measurements from the Cryogenically Operated Laser Diode (COLD) spectrometer (Viciani et al., 2008) onboard the high-flying research aircraft Geophysica.

The MOPITT remote sensing instrument was launched aboard the EOS Terra satellite on 18 December 1999; routine measurements began in March 2000. Terra is in a sun-synchronous orbit with an inclination of approximately $98.2^{\circ}$. MOPITT views the

20 Earth over all latitudes with a pixel size of $22 \times 22 \mathrm{~km}$ and a cross-track swath that provides a near-global measurement of the distribution of $\mathrm{CO}$ every three days. Operational MOPITT CO products in version 3 are based on $4.7 \mu \mathrm{m}$ thermal-channel radiances. The information content in MOPITT retrievals is quantified through the Degrees of Freedom for Signal (DFS) which indicates the number of independent pieces of information in the retrieved profile (Deeter et al., 2004). In the tropics and the mid-latitudes the DFS is in general greater then 1, which give some profile shape information, while a DFS of 1 indicates that the profile contains as much information as the column. The

\section{GMDD}

$4,1185-1211,2011$

CO as a tracer in CLaMS

R. Pommrich et al.

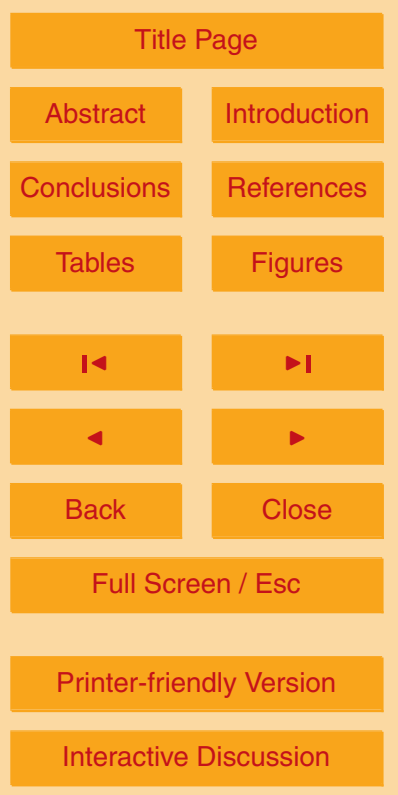


maximum sensitivity is located around $\sim 5 \mathrm{~km}, 500 \mathrm{hPa}$ (Deeter et al., 2003). Here we use the level 2 data of the version 3 retrievals of MOPITT CO that are extensively validated (e.g., Emmons et al., 2004; Emmons et al., 2007; Luo et al., 2007; Emmons et al., 2009, and references therein). Since 2009 the version 4 of MOPITT CO data 5 exists, described by Deeter et al. (2010).

MLS is one of four instruments on the EOS Aura satellite which was launched on 15 July 2004. MLS is viewing the Earth's limb in the orbit plane of the Aura spacecraft. Observations range from $82^{\circ} \mathrm{S}$ to $82^{\circ} \mathrm{N}$ every day and are spaced $140 \mathrm{~km}$ apart along the ground track. MLS detects thermally emitted radiation in several bands of the

sub-millimeter spectral region yielding profiles of temperature, geopotential height and the mixing ratio of more than fourteen chemical species. The mixing ratio of $\mathrm{CO}$ is obtained from measurements of the spectral line at $230 \mathrm{GHz}$. Here we use version 2.2 retrievals. The MLS retrieval technique is described in detail by Livesey et al. (2006) and the validation of the $2.2 \mathrm{CO}$ data product described by Pumphrey et al. (2007) and Livesey et al. (2008).

The COLD spectrometer is a Tunable Diode Laser (TDL) instrument designed for operation on a high-altitude aircraft for the measurement of CO (Viciani et al., 2008). The absolute in-flight accuracy for $\mathrm{CO}$ is 6\%-9\%. The precision is given by the value of either $1 \%$ of the mixing ratio or $7-8 \mathrm{ppb}$, depending on which value is the largest.

The time resolution of the data is $4 \mathrm{~s}$ which corresponds to a spatial resolution of about $800 \mathrm{~m}$ for an average airplane cruising speed of $750 \mathrm{~km} \mathrm{~h}^{-1}$ (Viciani et al., 2008).

\section{GMDD}

$4,1185-1211,2011$

$\mathrm{CO}$ as a tracer in CLaMS

R. Pommrich et al.

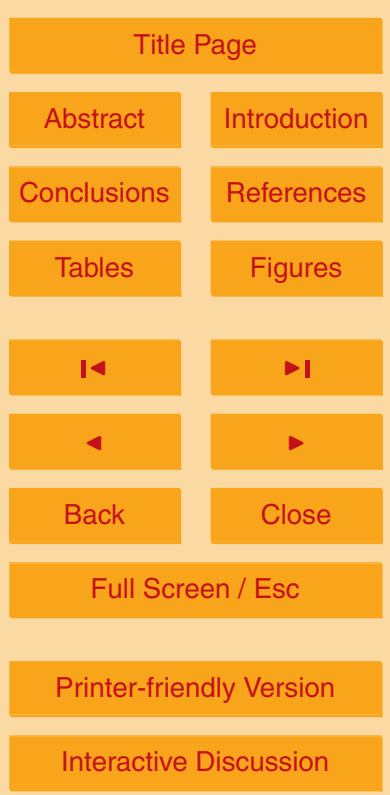




\section{Model description}

\subsection{The Chemical Lagrangian Model of the Stratosphere (CLaMS)}

\subsubsection{CLaMS transport}

CLaMS is a chemical transport model designed to simulate chemistry, advection, and 5 mixing in the stratosphere and upper troposphere (McKenna et al., 2002a,b; Konopka et al., 2007, 2010). Because of the Lagrangian representation of transport, with the intensity of mixing in model transport being driven by the strength of flow deformation, the model should be particularly well suited for the simulation of tracer transport in the vicinity of strong transport barriers and the associated tracer gradients. The specific model setup employed here follows closely the setup described by Konopka et al. $(2007,2010)$. The horizontal resolution is $100 \mathrm{~km}$ and the vertical resolution in the tropopause region about $400 \mathrm{~m}$. Multi-annual, global CLaMS simulations of the whole troposphere and stratosphere (from the ground up to the stratopause around $2500 \mathrm{~K}$ potential temperature) cover the time period from October 2001 to the end of 2008.

15 The model employs a hybrid coordinate $(\zeta)$ that corresponds to isentropic coordinates above $p_{r}=100 \mathrm{hPa}$ and smoothly transforms to a pressure based vertical coordinate below $p_{r}$ (Mahowald et al., 2002). The hybrid coordinate $\zeta$ is defined as

$\zeta(p)=f(\eta) \theta(p, T(p)), \quad \eta=\frac{p}{p_{0}}$

with

$f(\eta)= \begin{cases}\sin \left(\frac{\pi}{2} \frac{1-\eta}{1-\eta_{r}}\right) & \eta>\eta_{r} \\ 1 & \eta \leq \eta_{r}, \quad \eta_{r}=\frac{p_{r}}{p_{0}}, \quad p_{0}=1000 \mathrm{hPa}\end{cases}$

The use of this coordinate allows the tropospheric upwelling as it is represented in the pressure tendencies $(\dot{p}=\omega)$ of the ECMWF operational analysis to be represented

$\mathrm{CO}$ as a tracer in CLaMS

R. Pommrich et al.

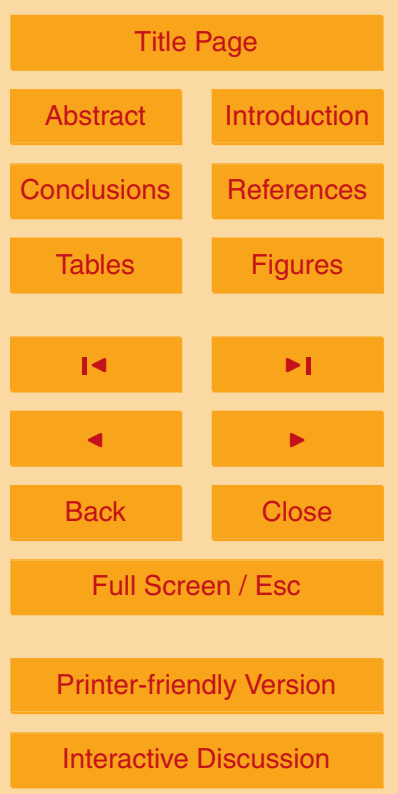

Interactive Discussion 
in the CLaMS transport (see Konopka et al., 2007, for details). However, a parametrization of subgrid scale convectively driven vertical transport, as it is present for example in the ECMWF model, is not included in this model version of CLaMS. Furthermore, in order to obtain mass-conserving transport on an annual scale the calculated vertical 5 velocities $\dot{\zeta}$ are corrected (Rosenlof, 1995; Konopka et al., 2010). In this way zonally and annually averaged total mass fluxes vanish across each $\zeta(\lambda)$ isoline ( $\lambda$, latitude).

\subsubsection{Simplified chemistry scheme}

The CLaMS model contains a detailed comprehensive stratospheric chemistry scheme including catalytic ozone loss cycles as well as heterogeneous chemistry on the surfaces of stratospheric aerosol particles and polar stratospheric clouds (McKenna et al., 2002a; Wegner et al., 2011). Here, the focus is on a limited set of trace species in the TTL, in particular on CO. Therefore, a strongly simplified chemistry is implemented in this model version, which is designed to describe reasonably well the first order chemical loss of long-lived tracers, ozone production and chemical loss in the TTL, and the production and loss of stratospheric $\mathrm{CO}$. There are four long lived tracers considered in the simplified chemistry scheme, namely $\mathrm{CH}_{4}, \mathrm{~N}_{2} \mathrm{O}, \mathrm{CCl}_{3} \mathrm{~F}$, and $\mathrm{CO}_{2}$. Ploeger et al. (2011) recently showed that the $\mathrm{O}_{3}$ budget in the upper TTL and lower stratosphere is well represented employing this simplified chemistry scheme. The reactions

\section{GMDD}

4, 1185-1211, 2011

$\mathrm{CO}$ as a tracer in CLaMS

R. Pommrich et al.

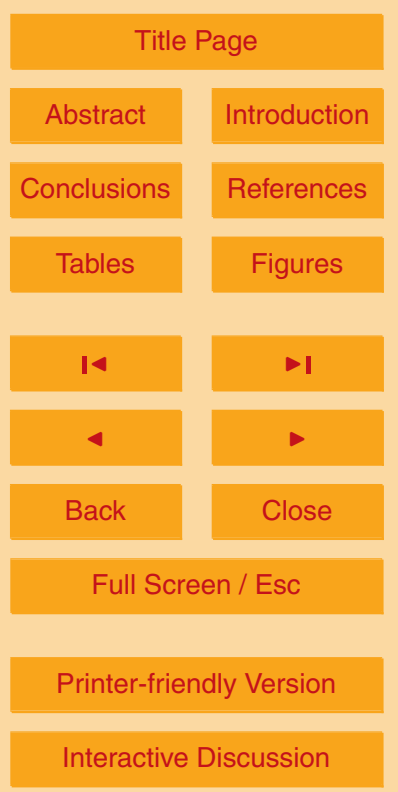


implemented in the model are:

$$
\begin{aligned}
\mathrm{CO}+\mathrm{OH} & \rightarrow \mathrm{CO}_{2}+\text { products } \\
\mathrm{CH}_{4}+\mathrm{OH} & \rightarrow 2 \mathrm{H}_{2} \mathrm{O}+\mathrm{CO} \\
\mathrm{CH}_{4}+\mathrm{O}\left({ }^{1} \mathrm{D}\right) & \rightarrow 2 \mathrm{H}_{2} \mathrm{O}+\mathrm{CO}+\text { products } \\
\mathrm{CH}_{4}+\mathrm{Cl} & \rightarrow 2 \mathrm{H}_{2} \mathrm{O}+\mathrm{CO}+\text { products } \\
\mathrm{N}_{2} \mathrm{O}+\mathrm{O}\left({ }^{1} \mathrm{D}\right) & \rightarrow \text { products } \\
\mathrm{N}_{2} \mathrm{O}+\mathrm{hv} & \rightarrow \text { products } \\
\mathrm{CCl}_{3} \mathrm{~F}+\mathrm{hv} & \rightarrow \text { products } \\
\mathrm{O}_{2}+\mathrm{hv} & \rightarrow 2 \mathrm{O}_{3} \\
\mathrm{O}_{3}+\mathrm{OH} & \rightarrow \mathrm{HO}_{2}+\mathrm{O}_{2} \times 2 \\
\mathrm{O}_{3}+\mathrm{HO}_{2} & \rightarrow \mathrm{OH}_{2} 2 \mathrm{O}_{2} \times 0
\end{aligned}
$$

Rate constants are deduced from current recommendations (Sander et al., 2006). The photolysis rates are calculated as diurnal averages using the CLaMS photolysis code (Becker et al., 2000). Products other than $\mathrm{CO}, \mathrm{O}_{3}$ or the four considered long-lived tracers are ignored in this approach.

5 Reaction (R9) constitutes the rate limiting step of the $\mathrm{HO}_{\mathrm{x}}$ catalytic ozone loss cycle (Reactions R9-R10) in which two ozone molecules are destroyed $\left(2 \mathrm{O}_{3} \rightarrow 3 \mathrm{O}_{2}\right)$. Thus, Reaction (R9) is assigned twice the recommended value to represent the ozone loss through this cycle and in turn, the rate of Reaction (R10) is set to zero. By this approach and by accounting for photochemical production of ozone through the photolysis of molecular oxygen Reaction (R8), the most important reactions that determine ozone concentrations in the lowermost stratosphere are represented in the model.

The concentrations of the radicals $\mathrm{Cl}, \mathrm{O}\left({ }^{1} \mathrm{D}\right), \mathrm{OH}$, and $\mathrm{HO}_{2}$ are prescribed as tabulated values as a function of latitude and pressure level for each month. There are two options. First, values for these radicals are deduced from diurnal averages of the 15 Mainz 2-D photochemical model (Grooß, 1996). Second, concentrations of methane and ozone are taken from the HALOE climatology (Grooß and Russell, 2005) and the 
radical concentrations are then calculated from a simulation of the box model version of CLaMS including the complete chemistry scheme (McKenna et al., 2002b) for each pressure level, longitude and month. These tabulated climatologies of $\mathrm{Cl}, \mathrm{O}\left({ }^{1}\right) \mathrm{D}$. $\mathrm{OH}$ and $\mathrm{HO}_{2}$ are available as electronical supplement of this paper, as they are considered 5 as the most reliable. However, the model results shown here are based on diurnal averages of the Mainz 2-D photochemical model.

\subsection{Boundary conditions for $\mathrm{CO}$ and long-lived tracers at the top and bottom of the model domain}

The model setup presented here is aimed at using $\mathrm{CO}$ as a tracer of tropospheric the detailed impact of tropospheric sources. Therefore, $\mathrm{CO}$ is prescribed in the free troposphere based on MOPITT measurements. We use the MOPITT measurements at $500 \mathrm{hPa}$, where MOPITT provides reliable measurements (Deeter et al., 2004; Emmons et al., 2004). Although reported at $500 \mathrm{hPa}$, due to the rather wide averaging kernels of MOPITT (Deeter et al., 2004), these values are influenced by the CO values in a thick layer $(\sim 200-700 \mathrm{hPa})$ in the free troposphere. MOPITT only reaches global coverage after three days and in addition the density of measurements is often limited by cloud occurrence. Therefore, we use trajectory calculations from the MOPITT measurement locations during a five day period, forward and backward, to $2012: 00$ UTC on the central day of the five day period. The data are binned into a $2^{\circ} \times 6^{\circ}$ latitude/longitude grid and then averaged on each grid point location weighted by the distance to the corresponding grid point location to construct the boundary condition for the central day. An example of the $\mathrm{CO}$ field on a regular grid derived in this way for 2 January 2008 is shown in Fig. 1.

25 The model levels below $500 \mathrm{hPa}$ are set to the $\mathrm{CO}$ values determined through the trajectory procedure described above, except in the lowest model level, where CO measurements from the NOAA/CMDL ground-based measurement network are prescribed
GMDD

$4,1185-1211,2011$

$\mathrm{CO}$ as a tracer in CLaMS

R. Pommrich et al.

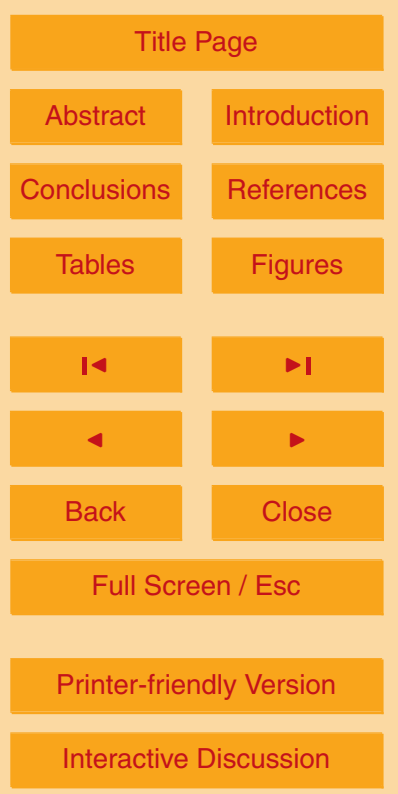

Interactive Discussion 
(Novelli et al., 2003) ${ }^{1}$. The CO fields deduced in this way, however, underestimate the $\mathrm{CO}$ total column measured by MOPITT. Thus, the prescribed $\mathrm{CO}$ values are corrected (scaled up by $20 \%$ ) so that the CO column in the model agrees more closely with the MOPITT CO column measurement. CO at the upper boundary $(\theta=2500 \mathrm{~K})$ is set 5 according to the Mainz-2D model (Grooß, 1996).

For the long lived tracers, $\mathrm{CO}_{2}, \mathrm{CH}_{4}, \mathrm{CCl}_{3} \mathrm{~F}$, and $\mathrm{N}_{2} \mathrm{O}$ boundary conditions are prescribed as mixing ratios in the lowest model level. For $\mathrm{CO}_{2}$ and $\mathrm{CH}_{4}$ the measurements from the NOAA/CMDL ground-based measurement network are used (Masarie and Tans, 1995; Novelli et al., 2003).

${ }_{10} \mathrm{CCl}_{3} \mathrm{~F}$ and $\mathrm{N}_{2} \mathrm{O}$ are derived from the in situ CATS instruments (CATSChromatograph for Atmospheric Trace Species) being in continuous operation at six NOAA baseline observatories since $1999^{2}$. At the upper boundary $\mathrm{CCl}_{3} \mathrm{~F}$ is set to zero, whereas the HALOE climatology (Grooß and Russell, 2005) and the Mainz-2D model $(\mathrm{Groo} ß, 1996)$ are used for $\mathrm{CH}_{4}$ and $\mathrm{N}_{2} \mathrm{O}$, respectively.

15 In addition, for the interpretation of the data and for the definition of the upper boundary of $\mathrm{CO}_{2}$, the mean age $\Gamma(\lambda, \phi)(\lambda$, latitude, $\phi$, longitude) is used. The mean age $\Gamma$ is determined by considering a linear increasing tracer in the boundary layer. $\Gamma$ is calculated as the time lag, at a given time, between the stratospheric tracer value and the tracer value in the boundary layer (Waugh and Hall, 2002). $\Gamma$ at $\zeta=2500 \mathrm{~K}$ is de20 rived from MIPAS observations of $\mathrm{SF}_{6}$ (Stiller et al., 2008). The upper boundary of $\mathrm{CO}_{2}$ is defined through: $\left[\mathrm{CO}_{2}\right](\lambda, \phi, t)=\left\langle\mathrm{CO}_{2}\right\rangle(t-\Gamma(\lambda, \phi))$, where $\left.<\mathrm{CO}_{2}\right\rangle$ denotes the mean value of $\mathrm{CO}_{2}$ in the tropics (zonally averaged in the latitude range $\pm 30^{\circ}$ ) calculated from the NOAA/CMDL ground-based measurement network. Thus, at the upper boundary, the $\mathrm{CO}_{2}$ distribution is derived from that in the tropical boundary layer

${ }^{1}$ see also http://www.esrl.noaa.gov/gmd/ccgg/globalview/co/co_intro.html

${ }^{2}$ http://www.esrl.noaa.gov/gmd/hats/insitu/cats/

GMDD

4, 1185-1211, 2011

CO as a tracer in CLaMS

R. Pommrich et al.

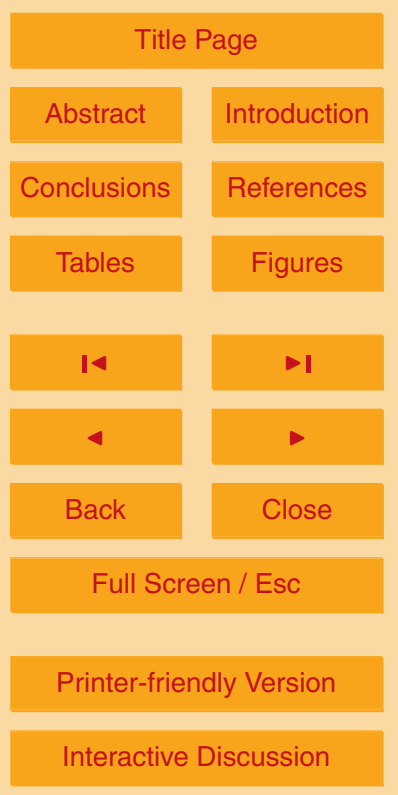

Interactive Discussion

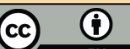


The volume mixing ratio of ozone at the surface is set to zero, between the surface and $\theta=500 \mathrm{~K}$ the volume mixing ratio of ozone is calculated based on the simplified chemistry scheme described earlier in this paper, above $\theta=500 \mathrm{~K}$ ozone is prescribed from the HALOE climatology (Grooß and Russell, 2005).

\section{$5 \quad 4$ Results}

\subsection{Comparison of simulated $\mathrm{CO}$ with measurements}

\subsubsection{MOPITT measurements}

In Fig. 2, we show a comparison of tropical CLaMS CO simulations with MOPITT measurements. CLaMS values are convoluted with the MOPITT averaging kernels and, like the MOPITT measurements, zonally averaged over the latitude band $\pm 15^{\circ}$. There is in general good agreement, particularly the seasonal variation of tropical $\mathrm{CO}$ is well represented. At $500 \mathrm{hPa}(\zeta \approx 250 \mathrm{~K})$ the average $\mathrm{CO}$ mixing ratios are close to the MOPITT measurements, at the levels above correspondence between the simulations and the measurements is less good. After end of 2006 there are bigger differences between the maxima (even at $250 \mathrm{~K}$ ) than in the years before, the correspondence for the lower values is equally good, as before 2006; the problems after 2006 are probably due to the introduction of a new ice supersaturation scheme in the ECMWF integrated forecast system (Tompkins et al., 2007) in September 2006. We discuss this point in the next section.

In Fig. 3, we show examples of a comparison of the results of the CLaMS simulations of $\mathrm{CO}$ anomaly with MOPITT measurements on the model surface $\zeta=350 \mathrm{~K}$; $\sim 150 \mathrm{hPa}$, close to the mean convective outflow level in the tropics. CLaMS values are convoluted with the MOPITT averaging kernels for an appropriate comparison. The overall agreement is satisfying for all the years. Differences occur mainly in the tropics. However, it is not surprising that the model shows a deficit in the tropics, because the
GMDD

$4,1185-1211,2011$

$\mathrm{CO}$ as a tracer in CLaMS

R. Pommrich et al.

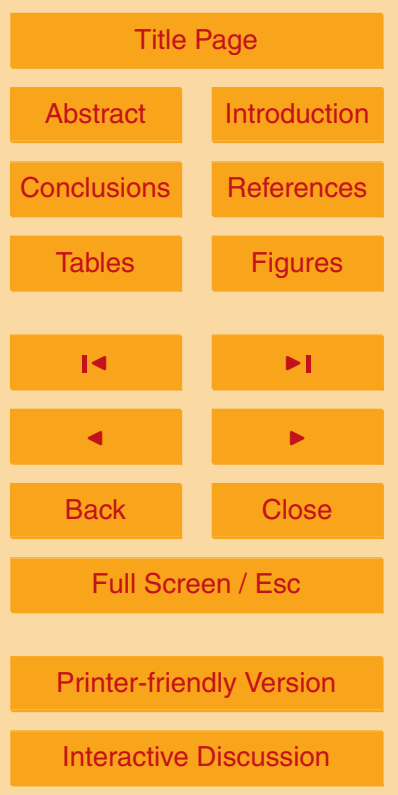


upward transport is represented in the model solely by the large-scale vertical winds $(\omega=\dot{p})$ which do not contain information of sub-grid scale, convectively driven vertical transport.

\subsubsection{MLS measurements}

5 An important test for the ability of a model to describe transport and chemistry of longer lived tropospheric tracers like $\mathrm{CO}$ in the tropical upper troposphere and lower stratosphere is the temporal development of anomaly signals in the air ascending in the tropics, commonly referred to as "atmospheric tape recorder" (Mote et al., 1996; Schoeberl et al., 2006). For a successful reproduction of the CO tape recorder pattern, a model needs to be able to describe correctly the seasonality of $\mathrm{CO}$ in the upper troposphere, the transport within the troposphere to the bottom of the TTL, where the seasonal CO pattern is imprinted on the ascending air (or where, in other words, the "tape head is written"). Further, the model needs to be driven with the appropriate vertical velocities for the upward transport in the tropical lower stratosphere without the anomaly pattern being destroyed by an excessive vertical or horizontal diffusion or incorrect chemistry. Finally, the extent of horizontal in-mixing into the TTL, which affects tape recorder patterns (Konopka et al., 2010) needs to be correctly described.

In Fig. 4, the simulated anomaly pattern of tropical, zonally averaged $\mathrm{CO}$ is shown, i.e. the CO "tape recorder". For an appropriate comparison, the CLaMS values were 20 vertically smoothed with a top hat function (with a width of $\sim 3 \mathrm{~km}$ ) to approximately take into account the field of view of the MLS instrument. The simulation successfully reproduced the observed approximately one-year tape recorder pattern of $\mathrm{CO}$ (Schoeberl et al., 2006; Liu et al., 2007). Further, the onset of enhanced as well as of reduced CO volume mixing ratios are well described. However, after September 2006, the

agreement between the CLaMS simulations of the CO anomaly pattern and the MLS CO observations is less good than before. In September 2006 a new ice supersaturation scheme was introduced in the ECMWF integrated forecast system (Tompkins et al., 2007). Therefore, we suggest that the impact of the new ice supersaturation

\section{GMDD}

$4,1185-1211,2011$

$\mathrm{CO}$ as a tracer in CLaMS

R. Pommrich et al.

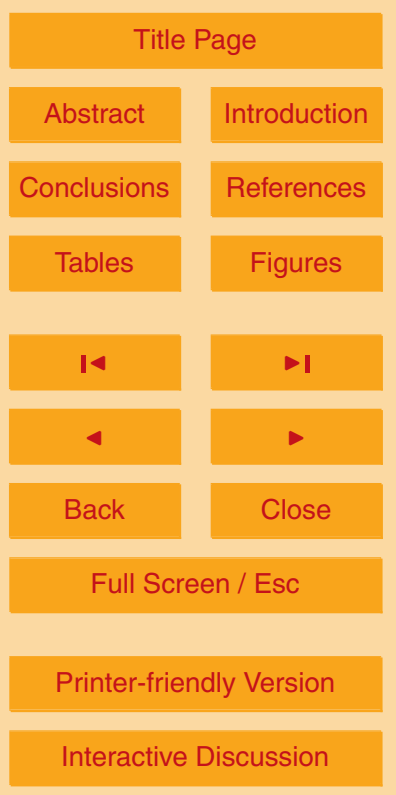

Interactive Discussion 
scheme on temperatures in the tropical lower stratosphere is responsible for the less good agreement after this date. Due to the introduction of the new scheme, the water vapour in the lower stratosphere increases in the operational analyses of ECMWF and, as a consequence, the air temperature increases. Higher temperatures in the TTL 5 mean smaller values of the diabatic heating due to the long-wave radiation derived in CLaMS from the Morcrette scheme under clear sky conditions (Morcrette, 1991). Consequently, tropical upwelling in the TTL decreases. We suggest that these lower vertical velocities are responsible for the underestimation of the $\mathrm{CO}$ concentrations in the lower tropical stratosphere after September 2006.

\subsubsection{COLD measurements}

Because of their high spatial and temporal resolution, the in-situ measurements of $\mathrm{CO}$ from the COLD instrument allow the quality of the vertical structure of $\mathrm{CO}$ in the CLaMS simulations to be evaluated. In Figs. 5 and 6 , we compare the vertical CO profile measured by COLD during two flights of the TROCCINOX campaign. The flight 15 on 5 February 2005 was planned in order to sample air masses influenced by both, fresh and aged convection while the flight of 15 February 2005 was a survey flight of the TTL aimed at sampling air at background conditions. The comparison for the flight on 5 February shows that in the CLaMS simulation, the low stratospheric mixing ratios of $\mathrm{CO}$ at altitudes greater than about $380 \mathrm{~K}$ are reproduced reasonably well. However, 20 the strong enhancement of $\mathrm{CO}$ at altitudes below, with peak values of $\mathrm{CO}$ of about $130 \mathrm{ppb}$ at $340-380 \mathrm{~K}$ are substantially underestimated. We attribute the strong CO enhancement at $340-380 \mathrm{~K}$ to air that is lofted by convection to these altitudes and thereafter injected into the upper troposphere in the convective outflow region. Indeed, while young air masses, with a simulated mean age of air of about half a month, are observed at $\approx 350 \mathrm{~K}$ the simulated mean age of air is not compatible with fresh convection. Consequently, we interpret the observed model underestimate of $\mathrm{CO}$ as being caused by the lack of a convective parametrization in CLaMS. The model produces some signature of convectively driven upward transport as a peak in the CO distribu-
GMDD

$4,1185-1211,2011$

CO as a tracer in CLaMS

R. Pommrich et al.

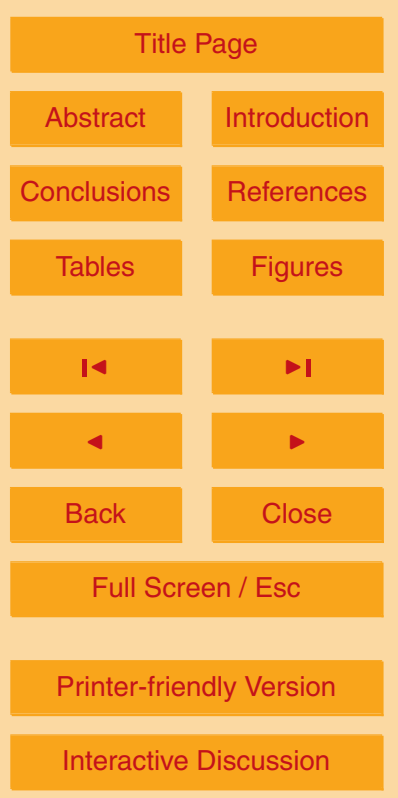

Interactive Discussion 
tion at about $330 \mathrm{~K}$ that coincides with very young air masses, recently being lofted from the ground. Thus, the ECMWF vertical winds $(\dot{p})$ employed in the CLaMS simulation discussed here contain some signature of the convective activity that was sampled during the Geophysica flight on 5 February 2005, albeit a much weaker one than in 5 reality.

The reproduction by the CLaMS simulations of $\mathrm{CO}$ mixing ratios measured on 15 February is much more successful than the simulation for 5 February. The agreement is generally reasonable with both the decline of $\mathrm{CO}$ with altitude above about $350 \mathrm{~K}$ and the enhancement in the upper troposphere being reproduced in the simula10 tion. There is some indication of an underestimate of the peak $\mathrm{CO}$ in the convective outflow region, but much less pronounced than for the flight on 5 February. Therefore, we conclude that the lack of a representation of subgrid scale convectively driven upward transport of trace species in the troposphere in CLaMS does not substantially impact the simulation of $\mathrm{CO}$ for tropical background conditions. For a successful representation of the impact on $\mathrm{CO}$ of individual convective events, such as observed for the flight on 5 February 2005, a model resolution at the spatial scales of convective events is necessary.

\section{Conclusions}

We presented a simplified chemistry scheme for the chemical transport model CLaMS 20

for the simulation of $\mathrm{CO}$, ozone, and long-lived trace substances $\left(\mathrm{CH}_{4}, \mathrm{~N}_{2} \mathrm{O}, \mathrm{CCl}_{3} \mathrm{~F}\right.$, and $\mathrm{CO}_{2}$ ) in the lower tropical stratosphere at comparatively low numerical cost. The boundary conditions at the ground are represented for the long-lived trace substances $\mathrm{CH}_{4}, \mathrm{~N}_{2} \mathrm{O}, \mathrm{CCl}_{3} \mathrm{~F}$, and $\mathrm{CO}_{2}$ based on ground-based measurements. The boundary conditions for $\mathrm{CO}$ in the free troposphere are based on MOPITT measurements. The

focus of this work is on the quality of the simulated $\mathrm{CO}$ fields (see Ploeger et al., 2011, for a discussion of the simulated ozone budget in the TTL). Comparison with in-situ measured CO profiles shows good agreement for background conditions, while

GMDD

$4,1185-1211,2011$

CO as a tracer in CLaMS

R. Pommrich et al.

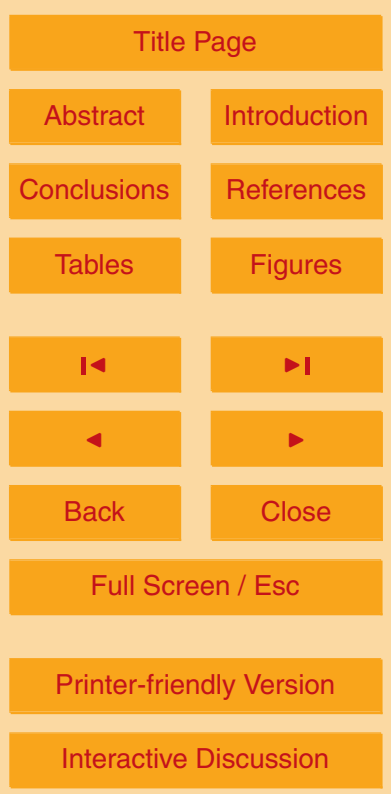

Interactive Discussion

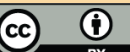


signatures of recent convective events are underestimated. We conclude that the lack of a parametrization of convectively driven upward transport in the tropical troposphere does not substantially impact the quality of the simulation of $\mathrm{CO}$ for background conditions in the tropical troposphere. Comparison of tropical CLaMS CO simulations with 5 MOPITT measurements in the upper troposphere $(500-250 \mathrm{hPa})$ show overall good agreement. However, this agreement, in particular for the winter maximum $\mathrm{CO}$ values, becomes worse after the end of 2006. We attribute the worse performance of the model under these conditions to the introduction of a new supersaturation scheme of the ECMWF (Tompkins et al., 2007) which leads to higher water vapour concentra10 tions in the tropical tropopause region, thus to higher temperatures and, consequently, to lower tropical ascent rates. Further, we find that the zonally averaged tropical $\mathrm{CO}$ anomaly patterns simulated by this model version of CLaMS are in good agreements with observations.

\section{Supplementary material related to this article is available online at: \\ 15 http://www.geosci-model-dev-discuss.net/4/1185/2011/gmdd-4-1185-2011-supplement. zip.}

Acknowledgements. The authors thank both the MOPITT and the MLS team for providing such great research products publically available. We thank Felix Ploeger for helpful comments on the manuscript. TROCCINOX was partially funded by the Commission of the European

\section{References}

Becker, G., Grooß, J.-U., McKenna, D. S., and Müller, R.: Stratospheric photolysis frequencies: Impact of an improved numerical solution of the radiative transfer equation, J. Atmos. Chem., 37, 217-229, doi:10.1023/A:1006468926530, 2000. 1192

Deeter, M. N., Emmons, L. K., Francis, G. L., Edwards, D. P., Gille, J. C., Warner, J. X., Khattatov, B., Ziskin, D., Lamarque, J.-F., Ho, S.-P., Yudin, V., Attié, J.-L., Packman,

GMDD

4, 1185-1211, 2011

$\mathrm{CO}$ as a tracer in CLaMS

R. Pommrich et al.

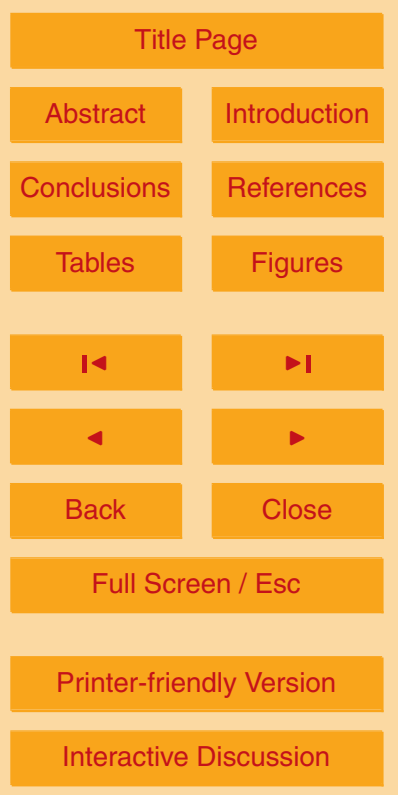

Interactive Discussion

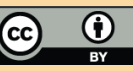


D., Chen, J., Mao, D., and Drummond, J. R.: Operational carbon monoxide retrieval algorithm and selected results for the MOPITT instrument, J. Geophys. Res., 108, 4399, doi:10.1029/2002JD003186, 2003. 1187, 1188, 1189

Deeter, M. N., Emmons, L. K., Edwards, D. P., and Gille, J. C.: Vertical resolution and information content of CO profiles retrieved by MOPITT, Geophys. Res. Lett., 31, L15112, doi:10.1029/2004GL020235, 2004. 1188, 1193

Deeter, M. N., Edwards, D. P., Gille, J. C., Emmons, L. K., Francis, G., Ho, S.-P., Mao, D., Masters, D., Worden, H., Drummond, J. R., and Novelli, P. C.: The MOPITT version 4 CO product: Algorithm enhancements, validation, and long-term stability, J. Geophys. Res., 115, D07306, doi:10.1029/2009JD013005, 2010. 1189

Emmons, L. K., Deeter, M. N., Gille, J. C., Edwards, D. P., Attié, J.-L., Warner, J., Ziskin, D., Francis, G., Khattatov, B., Yudin, V., Lamarque, L.-F., Ho, S.-P., Mao, D., Chen, J. S., Drummond, J., Novelli, P., Sachse, G., Coffey, M. T., Hannigan, J. W., Gerbig, C., Kawakami, S., Kondo, Y., Takegawa, N., Schlager, H., Baehr, J., and Ziereis, H.: Validation of Measurements of Pollution in the Troposphere (MOPITT) CO retrievals with aircraft in situ profiles, J. Geophys. Res., 109, D03309, doi:10.1029/2003JD004101, 2004. 1189, 1193

Emmons, L. K., Pfister, G. G., Edwards, D. P., Gille, J. C., Sachse, G., Blake, D., Wofsy, S., Gerbig, C., Matross, D., and Nédélec, P.: Measurements of Pollution in the Troposphere (MOPITT) validation exercises during summer 2004 field campaigns over North America, J. Geophys. Res., 112, D12S02, doi:10.1029/2006JD007833, 2007. 1189

Emmons, L. K., Edwards, D. P., Deeter, M. N., Gille, J. C., Campos, T., Nédélec, P., Novelli, P., and Sachse, G.: Measurements of Pollution In The Troposphere (MOPITT) validation through 2006, Atmos. Chem. Phys., 9, 1795-1803, http://www.atmos-chem-phys.net/9/1795/2009/, 2009. 1189

Fueglistaler, S., Dessler, A. E., Dunkerton, T. J., Folkins, I., Fu, Q., and Motte, P. W.: Tropical tropopause layer, Rev. Geophys., RG1004, doi:10.1029/2008RG000267, 2009. 1187

Garcia, R. R., Marsh, D. R., Kinnison, D. E., Boville, B. A., and Sassi, F.: Simulation of secular trends in the middle atmosphere, 1950-2003, J. Geophys. Res., 112, D09301, doi:10.1029/2006JD007485, 2007. 1187

30 Grooß, J.-U.: Modelling of Stratospheric Chemistry based on HALOE/UARS Satellite Data, PhD thesis, University of Mainz, 1996. 1192, 1194

Grooß, J.-U. and Müller, R.: Simulation of ozone loss in Arctic winter 2004/2005, Geophys. Res. Lett., 34, L05804, doi:10.1029/2006GL028901, 2007. 1187
GMDD

$4,1185-1211,2011$

$\mathrm{CO}$ as a tracer in CLaMS

R. Pommrich et al.

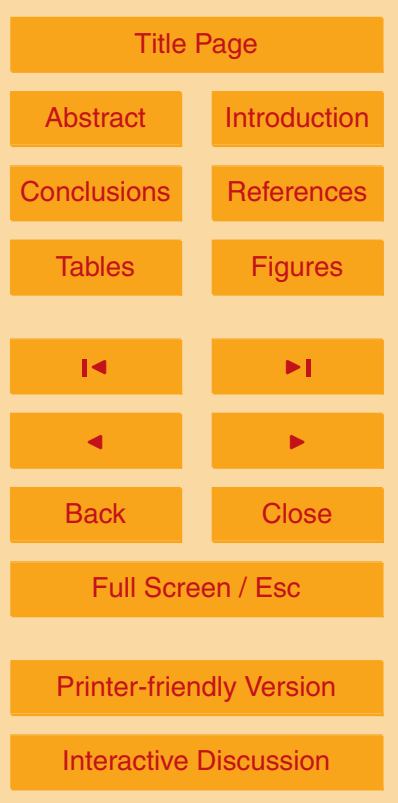


Grooß, J.-U. and Russell III, James, M.: Technical note: A stratospheric climatology for $\mathrm{O}_{3}$, $\mathrm{H}_{2} \mathrm{O}, \mathrm{CH}_{4}, \mathrm{NOx}, \mathrm{HCl}$ and $\mathrm{HF}$ derived from HALOE measurements, Atmos. Chem. Phys., 5, 2797-2807, doi:10.5194/acp-5-2797-2005, 2005. 1192, 1194, 1195

Grooß, J.-U., Günther, G., Konopka, P., Müller, R., McKenna, D. S., Stroh, F., Vogel, B., Engel, $5 \quad$ A., Müller, M., Hoppel, K., Bevilacqua, R., Richard, E., Webster, C. R., Elkins, J. W., Hurst, D. F., Romashkin, P. A., and Baumgardner, D. G.: Simulation of ozone depletion in spring 2000 with the Chemical Lagrangian Model of the Stratosphere (CLaMS), J. Geophys. Res., 107, 8295, doi:10.1029/2001JD000456, 2002. 1187

Homan, C. D., Volk, C. M., Kuhn, A. C., Werner, A., Baehr, J., Viciani, S., Ulanovski, A., and Ravegnani, F.: Tracer measurements in the tropical tropopause layer during the AMMA/SCOUT-O3 aircraft campaign, Atmos. Chem. Phys., 10, 3615-3627, doi:10.5194/acp-10-3615-2010, 2010. 1187

Jöckel, P., Tost, H., Pozzer, A., Brühl, C., Buchholz, J., Ganzeveld, L., Hoor, P., Kerkweg, A., Lawrence, M. G., Sander, R., Steil, B., Stiller, G., Tanarhte, M., Taraborrelli, D., van Aardenne, J., and Lelieveld, J.: The atmospheric chemistry general circulation model ECHAM5/MESSy1: consistent simulation of ozone from the surface to the mesosphere, Atmos. Chem. Phys., 6, 5067-5104, doi:10.5194/acp-6-5067-2006, 2006. 1187

Konopka, P., Steinhorst, H.-M., Grooß, J.-U., Günther, G., Müller, R., Elkins, J. W., Jost, H.J., Richard, E., Schmidt, U., Toon, G., and McKenna, D. S.: Mixing and Ozone Loss in the 1999-2000 Arctic Vortex: Simulations with the 3-dimensional Chemical Lagrangian Model of the Stratosphere (CLaMS), J. Geophys. Res., 109, D02315, doi:10.1029/2003JD003792, 2004. 1187

Konopka, P., Günther, G., Müller, R., dos Santos, F. H. S., Schiller, C., Ravegnani, F., Ulanovsky, A., Schlager, H., Volk, C. M., Viciani, S., Pan, L. L., McKenna, D.-S., and Riese, M.: Contribution of mixing to upward transport across the tropical tropopause layer (TTL), Atmos. Chem. Phys., 7, 3285-3308, doi:10.5194/acp-7-3285-2007, 2007. 1187, 1190, 1191

Konopka, P., Grooß, J.-U., Günther, G., Ploeger, F., Pommrich, R., Müller, R., and Livesey, N.: Annual cycle of ozone at and above the tropical tropopause: observations versus simulations with the Chemical Lagrangian Model of the Stratosphere (CLaMS), Atmos. Chem. Phys., 10, 121-132, doi:10.5194/acp-10-121-2010, 2010. 1187, 1190, 1191, 1196

Liu, C., Zipser, E., Garrett, T., Jiang, J. H., and Su, H.: How do the water vapor and carbon monoxide "tape recorder" start near the tropical tropopause?, Geophys. Res. Lett., 34, L09804, doi:10.1029/2006GL029234, 2007. 1187, 1196

\section{GMDD}

4, 1185-1211, 2011

$\mathrm{CO}$ as a tracer in CLaMS

R. Pommrich et al.

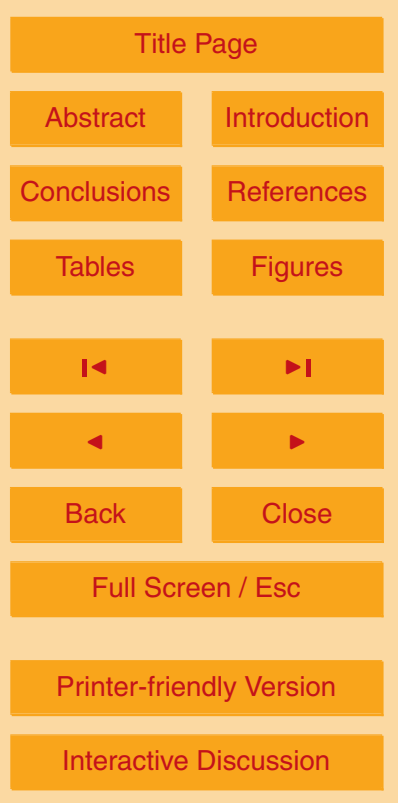


Livesey, N. J., Snyder, W. V., Read, W. G., and Wagner, P.: Retrieval algorithms for the EOS Microwave Limb Sounder (MLS) instrument, IEEE Trans. Geosci. Remote Sens., 44, 11441155, 2006. 1189

Livesey, N. J., Filipiak, M. J., Froidevaux, L., Read, W. G., Lambert, A., Santee, M. L., Jiang, $5 \quad$ J. H., Pumphrey, H. C., Waters, J. W., Cofield, R. E., Cuddy, D. T., Daffer, W. H., Drouin, B. J., Fuller, R. A., Jarnot, R. F., Jiang, Y. B., Knosp, B. W., Li, Q. B., Perun, V. S., Schwartz, M. J., Snyder, W. V., Stek, P. C., Thurstans, R. P., Wagner, P. A., Avery, M., Browell, E. V., Cammas, J.-P., Christensen, L. E., Diskin, G. S., Gao, R.-S., Jost, H.-J., Loewenstein, M., Lopez, J. D., Nedelec, P., Osterman, G. B., Sachse, G. W., and Webster, C. R.: Validation of Aura Microwave Limb Sounder $\mathrm{O}_{3}$ and $\mathrm{CO}$ observations in the upper troposphere and lower stratosphere, J. Geophys. Res., 113, D15S02, doi:10.1029/2007JD008805, 2008. 1189

Luo, M., Rinsland, C. P., Rodgers, C. D., Logan, J. A., Worden, H., Kulawik, S., Eldering, A., Goldman, A., Shephard, M. W., Gunson, M., and Lampel, M.: Comparison of carbon monoxide measurements by TES and MOPITT: Influence of a priori data and instrument characteristics on nadir atmospheric species retrieval, J. Geophys. Res., 112, D09303, doi:10.1029/2006JD007663, 2007. 1189

Mahowald, N. M., Plumb, R. A., Rasch, P. J., del Corral, J., and Sassi, F.: Stratospheric transport in a three-dimensional isentropic coordinate model, J. Geophys. Res., 107, 4254, doi:10.1029/2001JD001313, 2002. 1190

Masarie, K. and Tans, P.: Extension and integration of atmospheric carbon dioxide data into a globally consistent measurement record, J. Geophys. Res., 100, 11593-11610, 1995. 1194

McKenna, D. S., Grooß, J.-U., Günther, G., Konopka, P., Müller, R., Carver, G., and Sasano, Y.: A new Chemical Lagrangian Model of the Stratosphere (CLaMS): 2. Formulation of chemistry scheme and initialization, J. Geophys. Res., 107, 4256, doi:10.1029/2000JD000113, 2002a. 1187, 1190, 1191

McKenna, D. S., Konopka, P., Grooß, J.-U., Günther, G., Müller, R., Spang, R., Offermann, D., and Orsolini, Y.: A new Chemical Lagrangian Model of the Stratosphere (CLaMS): 1. Formulation of advection and mixing, J. Geophys. Res., 107, 4309, doi:10.1029/2000JD000114, 2002b. 1187, 1190, 1193

30 Morcrette, J.-J.: Radiation and Cloud Radiative Properties in the European Centre for MediumRange Weather Forecasts Forecasting System, J. Geophys. Res., 96, 9121-9132, 1991. 1197

Morgenstern, O., Braesicke, P., O’Connor, F. M., Bushell, A. C., Johnson, C. E., Osprey, S.

\section{GMDD}

$4,1185-1211,2011$

$\mathrm{CO}$ as a tracer in CLaMS

R. Pommrich et al.

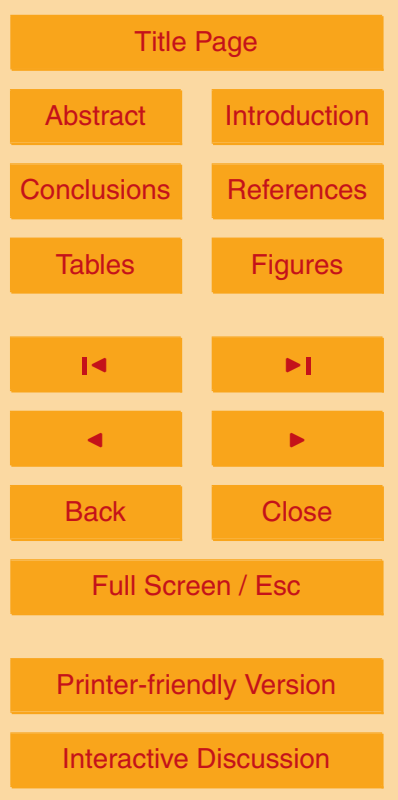


M., and Pyle, J. A.: Evaluation of the new UKCA climate-composition model - Part 1: The stratosphere, Geosci. Model Dev., 2, 43-57, doi:10.5194/gmd-2-43-2009, 2009. 1187

Mote, P. W., Rosenlof, K. H., McIntyre, M. E., Carr, E. S., Gille, J. G., Holton, J. R., Kinnersley, J. S., Pumphrey, H. C., Russell III, J. M., and Waters, J. W.: An atmospheric tape recorder: 5 The imprint of tropical tropopause temperatures on stratospheric water vapor, J. Geophys. Res., 101, 3989-4006, 1996. 1187, 1196

Novelli, C., P., Masarie, K. A., Lang, P. M., Hall, B. D., Myers, R. C., and Elkins., J. W.: Reanalysis of tropospheric CO trends: Effects of the 1997-1998 wildfires, J. Geophys. Res., 108, 4464, doi:10.1029/2002JD003031, 2003. 1194

10 Pan, L. L., Konopka, P., and Browell, E. V.: Observations and model simulations of mixing near the extratropical tropopause, J. Geophys. Res., 111, D05106, doi:10.1029/2005JD006480, 2006. 1187

Park, M., Randel, W. J., Emmons, L. K., Bernath, P. F., Walker, K. A., and Boone, C. D.: Chemical isolation in the Asian monsoon anticyclone observed in Atmospheric Chemistry Experiment (ACE-FTS) data, J. Geophys. Res., 112, D16309, doi:10.1029/2006JD008294, 2007. 1187

Park, M., Randel, W. J., Emmons, L. K., Bernath, P. F., Walker, K. A., and Boone, C. D.: Chemical isolation in the Asian monsoon anticyclone observed in Atmospheric Chemistry Experiment (ACE-FTS) data, Atmos. Chem. Phys., 8, 757-764, doi:10.5194/acp-8-757-2008, 2008. 1187

Ploeger, F., Fueglistaler, S., Grooß, J.-U., Günther, G., Konopka, P., Liu, Y.S., Müller, R., Ravegnani, F., Schiller, C., Ulanovski, A., and Riese, M.: Insight from ozone and water vapour on transport in the tropical tropopause layer (TTL), Atmos. Chem. Phys., 11, 407419, doi:10.5194/acp-11-407-2011, 2011. 1191, 1198

Pommrich, R., Müller, R., Grooß, J.-U., Konopka, P., Günther, G., Heil, A., Schultz, M., Pumphrey, H.-C., and Riese, M.: Simulation of the atmospheric tape recorder signal in HCN, Geophys. Res. Lett., 37, L16805, doi:10.1029/2010GL044056, 2010. 1187

Pumphrey, H. C., Filipiak, M. J., Livesey, N. J., Schwartz, M. J., Boone, C., Walker, K. A., Bernath, P., Ricaud, P., Barret, B., Clerbaux, C., Jarnot, R. F., Manney, G. L., and Waters, J. W.: Validation of middle-atmosphere carbon monoxide retrievals from MLS on Aura, J. Geophys. Res., 112, D24S38, doi:10.1029/2007JD008723, 2007. 1189

Pumphrey, H. C., Boone, C., Walker, K. A., Bernath, P., and Livesey, N. J.: Tropical tape recorder observed in HCN, Geophys. Res. Lett., 35, L05801, doi:10.1029/2007GL032137,
GMDD

4, 1185-1211, 2011

$\mathrm{CO}$ as a tracer in CLaMS

R. Pommrich et al.

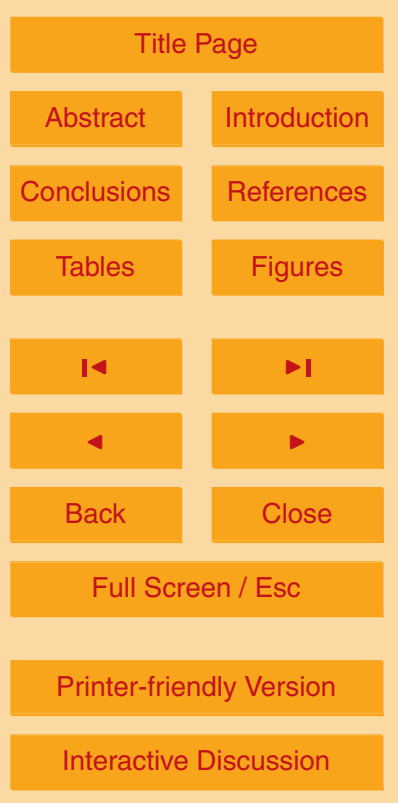

Interactive Discussion 
2008. 1187

Randel, W. J., Park, M., Wu, F., and Livesey, N.: A large annual cycle in ozone above the tropical tropopause linked to the Brewer-Dobson circulation, J. Atmos. Sci., 64, 4479-4488, 2007. 1187

5 Ricaud, P., Barret, B., Attié, J.-L., Motte, E., Le Flochmoën, E., Teyssèdre, H., Peuch, V.-H., Livesey, N., Lambert, A., and Pommereau, J.-P.: Impact of land convection on tropospherestratosphere exchange in the tropics, Atmos. Chem. Phys., 7, 5639-5657, doi:10.5194/acp7-5639-2007, 2007. 1187

Rosenlof, K. H.: Seasonal cycle of the residual mean meridional circulation in the stratosphere, J. Geophys. Res., 100, 5173-5191, 1995. 1191

Sander, S. P., Friedl, R. R., Golden, D. M., Kurylo, M. J., Huie, R. E., Orkin, V. L., Moortgat, G. K., Wine, P. H., Ravishankara, A. R., Kolb, C. E., Molina, M. J., and Finlayson-Pitts, B. J.: Evaluation number 15, Chemical kinetics and photochemical data for use in atmospheric studies, NASA Panel for Data Evaluation, JPL Publication 06-2, Jet Propulsion Laboratory,

15 California Insitute of Technology, Pasadena, California, 523 pp., 2006. 1192

Schoeberl, M. R., Duncan, B., Douglass, A. R., Waters, J., Livesey, N. J., Read, W., and Filipiak, M.: The carbon monoxide tape recorder, Geophys. Res. Lett., 33, L12811, doi:10.1029/2006GL026178, 2006. 1186, 1187, 1196

Schultz, M. G., Heil, A., Hoelzemann, J. J., Spessa, A., Thonicke, K., Goldammer, J. G., Held, A. C., Pereira, J. M. C., and van het Bolscher, M.: Global wildland fire emissions from 1960 to 2000, Global Biogeochem. Cy., 22, GB2002, doi:10.1029/2007GB003031, 2008. 1187

Stiller, G. P., von Clarmann, T., Höpfner, M., Glatthor, N., Grabowski, U., Kellmann, S., Kleinert, A., Linden, A., Milz, M., Reddmann, T., Steck, T., Fischer, H., Funke, B., López-Puertas, M., and Engel, A.: Global distribution of mean age of stratospheric air from MIPAS SF6 measurements, Atmos. Chem. Phys., 8, 677-695, doi:10.5194/acp-8-677-2008, 2008. 1194

Tompkins, A. M., Gierens, K., and Rädel, G.: Ice supersaturation in the ECMWF Integrated Forecast System., Q. J. R. Meteorol. Soc., 133, 53-63, 2007. 1196, 1199

Viciani, S., D’Amato, F., Mazzinghi, P., Castagnoli, F., Toci, G., and Werle, P.: A cryogenically operated laser diode spectrometer for airborne measurement of stratospheric trace gases, Appl. Phys. B, 90, 581-592, doi:10.1007/s00340-007-2885-2, 2008. 1188, 1189

Vogel, B., Pan, L. L., Konopka, P., Günther, G., Müller, R., Campos, T., Hall, W., Pollack, I., Weinheimer, A., Wei, J., Atlas, E. L., and Bowman, K. P.: Transport pathways and signatures of mixing in the extratropical tropopause region derived from Lagrangian model simulations,

GMDD

$4,1185-1211,2011$

$\mathrm{CO}$ as a tracer in CLaMS

R. Pommrich et al.

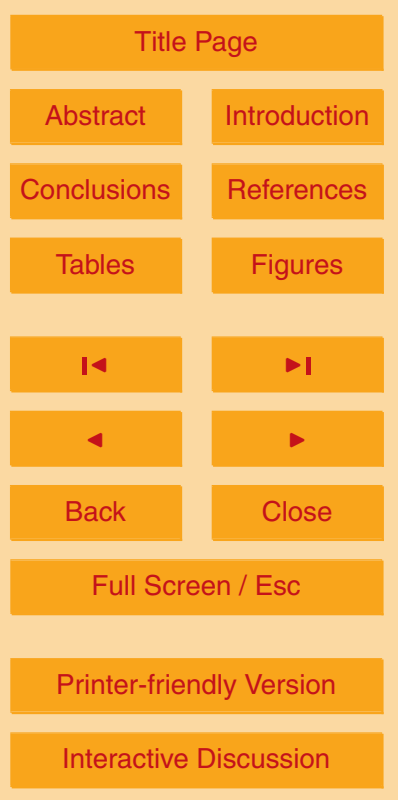

1204 
J. Geophys. Res., 116, doi:10.1029/2010JD014876, 2011. 1187

Waters, J. W., Froidevaux, L., Harwood, R. S., Jarnot, R. F., Pickett, H. M., Read, W. G., Siegel, P. H., Cofield, R. E., Filipiak, M. J., Flower, D. A., Holden, J. R., Lau, G. K., Livesey, N. J., Manney, G. L., Pumphrey, H. C., Santee, M. L., Wu, D. L., Cuddy, D. T., Lay, R. R., Loo, M. S., Perun, V. S., Schwartz, M. J., Stek, P. C., Thurstans, R. P., Boyles, M. A., Chandra, S., Chavez, M. C., Chen, G.-S., Chudasama, B. V., Dodge, R., Fuller, R. A., Girard, M. A., Jiang, J. H., Jiang, Y., Knosp, B. W., LaBelle, R. C., Lam, J. C., Lee, K. A., Miller, D., Oswald, J. E., Patel, N. C., Pukala, D. M., Quintero, O., Scaff, D. M., Snyder, W. V., Tope, M. C., Wagner, P. A., and Walch, M. J.: The Earth Observing System Microwave Limb Sounder (EOS MLS) on the Aura satellite, IEEE Trans. Geosci. Remote Sens., 44, 1106-1121, 2006. 1188

Waugh, D. W. and Hall, T. M.: Age of stratospheric air: Theory, observations, and models, Rev. Geophys., 40, 1-27, 2002. 1194

Wegner, T., Grooß, J.-U., von Hobe, M., Stroh, F., Volk, C. M., and Müller, R.: Chlorine activation in Arctic spring 2004/05, Atmos. Chem. Phys., to be submitted, 2011. 1191

\section{GMDD}

$4,1185-1211,2011$

$\mathrm{CO}$ as a tracer in CLaMS

R. Pommrich et al.

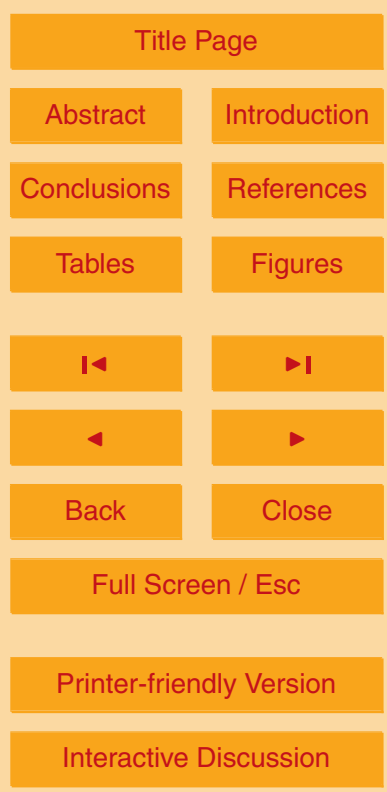




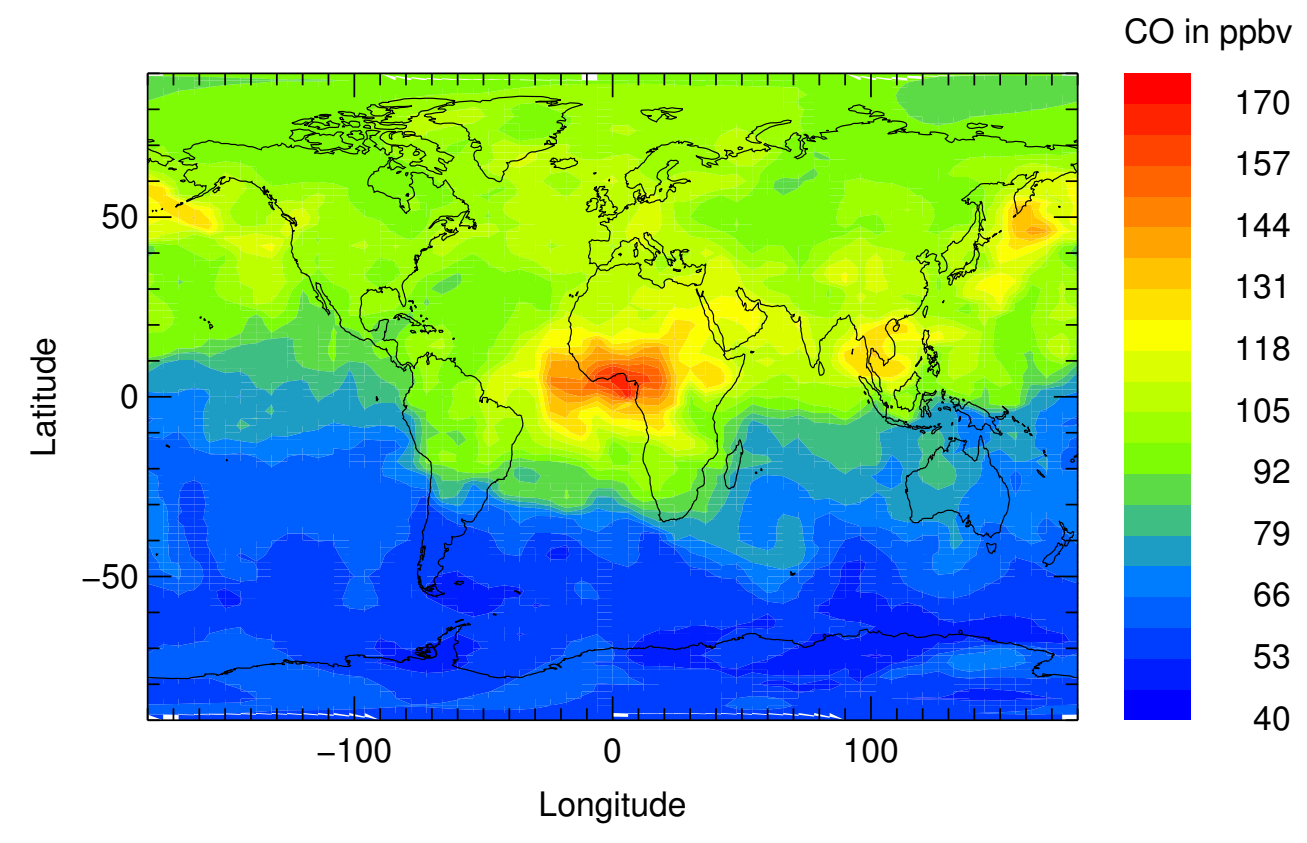

\section{GMDD}

$4,1185-1211,2011$

$\mathrm{CO}$ as a tracer in CLaMS

R. Pommrich et al.

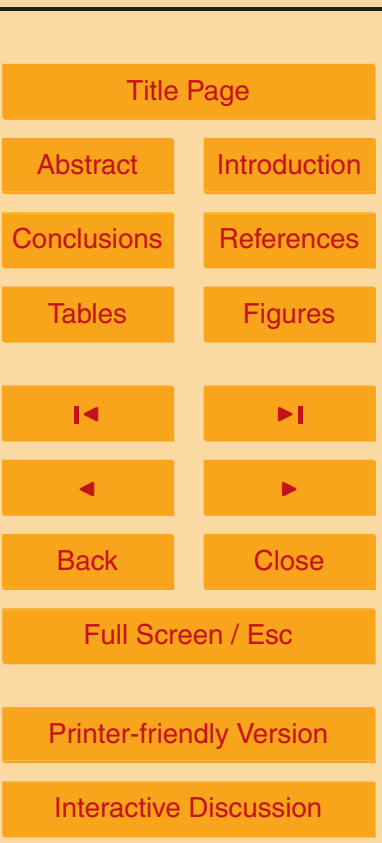

Fig. 1. Mixing ratios of $\mathrm{CO}$ on the $500 \mathrm{hPa}$ level on 2 January 2008, as derived from five days of MOPITT measurements by a trajectory technique. (See text for details).

Interactive Discussion 

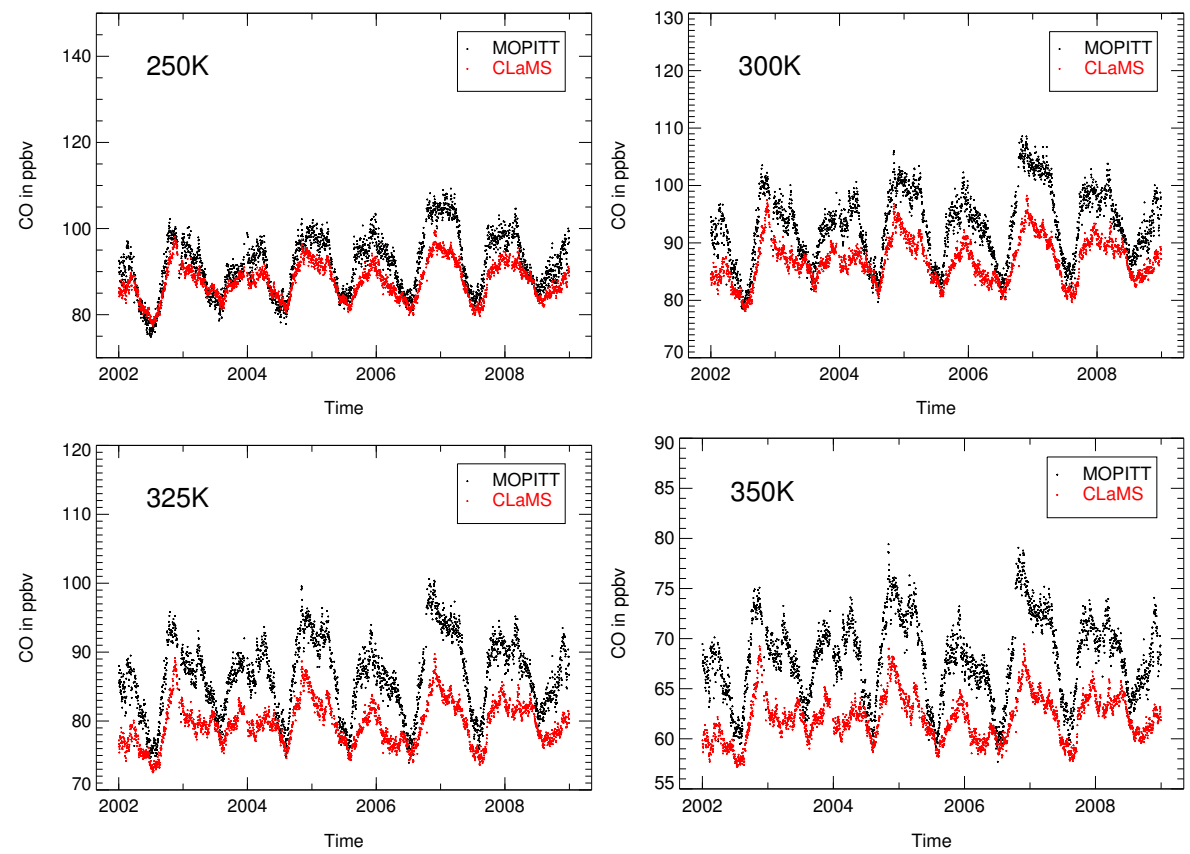

Fig. 2. Comparison of tropical CLaMS CO simulations (red) with MOPITT measurements (black) from the beginning of 2002 to the end of 2008. For an appropriate comparison the CLaMS values are convoluted with the MOPITT averaging kernels and, like the MOPITT measurements, zonally averaged over the latitude band of $\pm 15^{\circ}$. The comparison is done for the CLaMS model levels $\xi=250 \mathrm{~K}, 300 \mathrm{~K}, 325 \mathrm{~K}$, and $350 \mathrm{~K}$ corresponding to pressure levels of $500 \mathrm{hPa}, 350 \mathrm{hPa}, 250 \mathrm{hPa}$, and $150 \mathrm{hPa}$, respectively. The shift between the red and the black lines indicates the model bias.
GMDD

$4,1185-1211,2011$

$\mathrm{CO}$ as a tracer in CLaMS

R. Pommrich et al.

Title Page

Abstract

Introduction

Conclusions

References

Tables

Figures

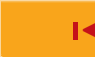

14
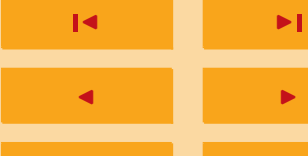

Back

Close

Full Screen / Esc

Printer-friendly Version

Interactive Discussion 

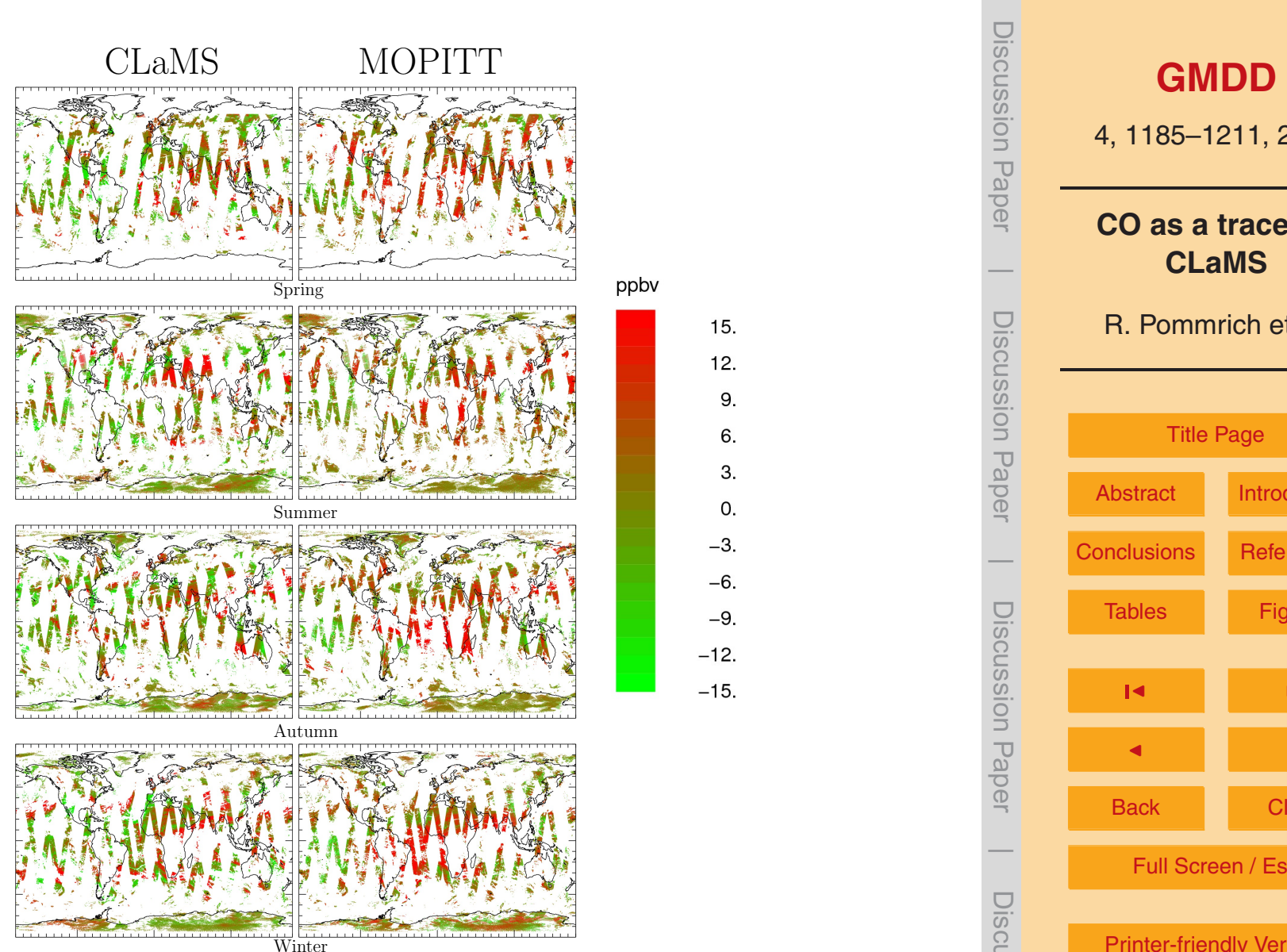

4, 1185-1211, 2011

CO as a tracer in CLaMS

R. Pommrich et al.

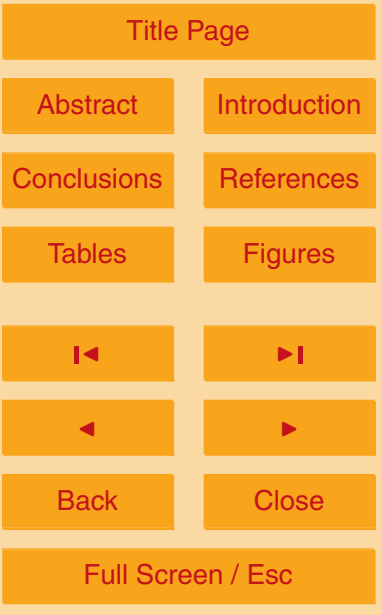

Printer-friendly Version

Fig. 3. Comparison of the anomalies of the CLaMS simulations and the MOPITT measurements of $\mathrm{CO}$ on the model surface $\xi=350 \mathrm{~K} ; 150 \mathrm{hPa}$ by showing the differences between the values and the respective zonal mean for the four seasons. For an appropriate comparison, the CLaMS values were convoluted with the MOPITT averaging kernels. 


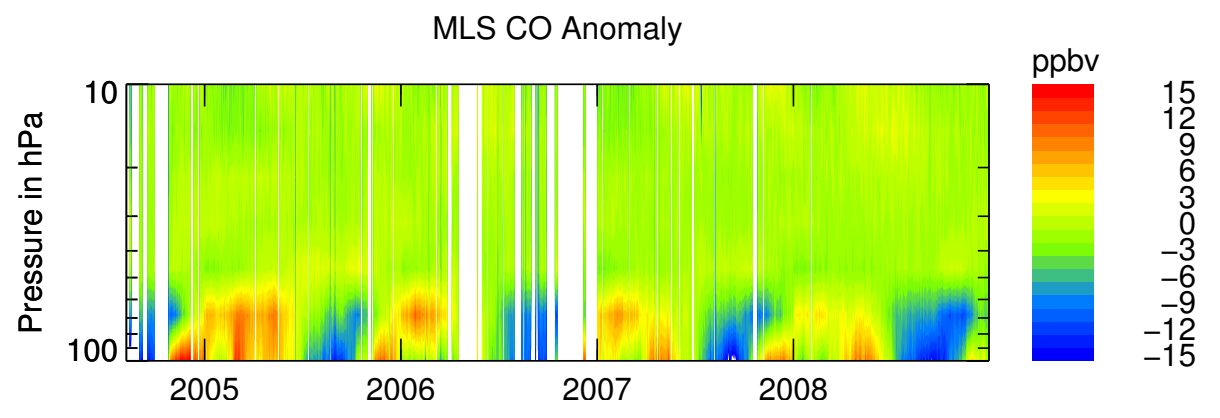

GMDD

$4,1185-1211,2011$

CO as a tracer in CLaMS

R. Pommrich et al.

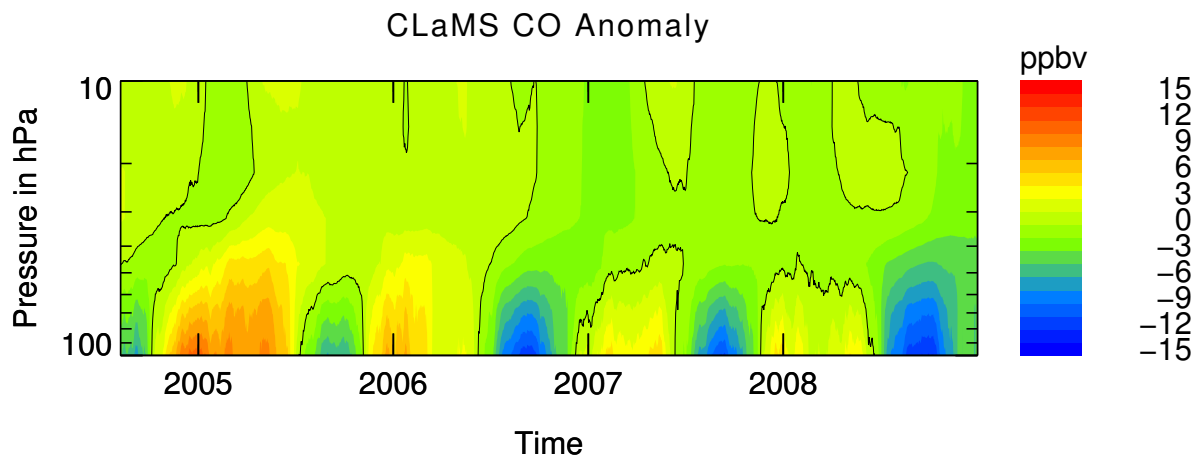

Fig. 4. Comparison of $\mathrm{CO}$ anomalies, zonally averaged in the latitude band $\pm 15^{\circ}$ from MLS measurements (top panel) and the CLaMS simulation (bottom panel) for the time period 8 August 2004 to 29 December 2008. The CLaMS values were vertically smoothed with a top hat function (with a width of $\sim 3 \mathrm{~km}$ ) to approximately take into account the field of view of the MLS instrument. The black lines indicates where the anomaly is zero.

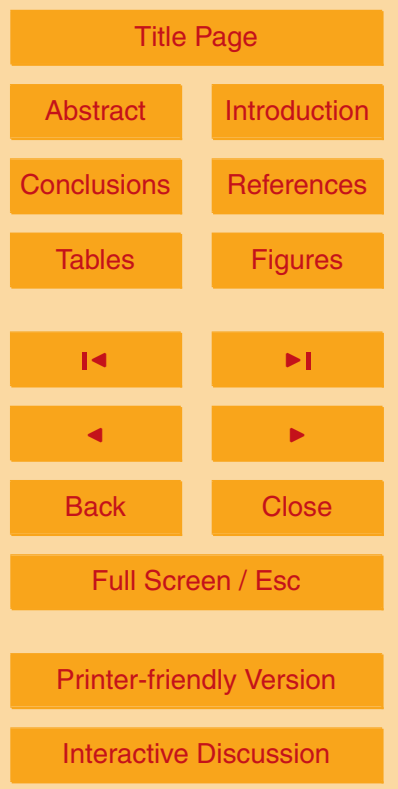




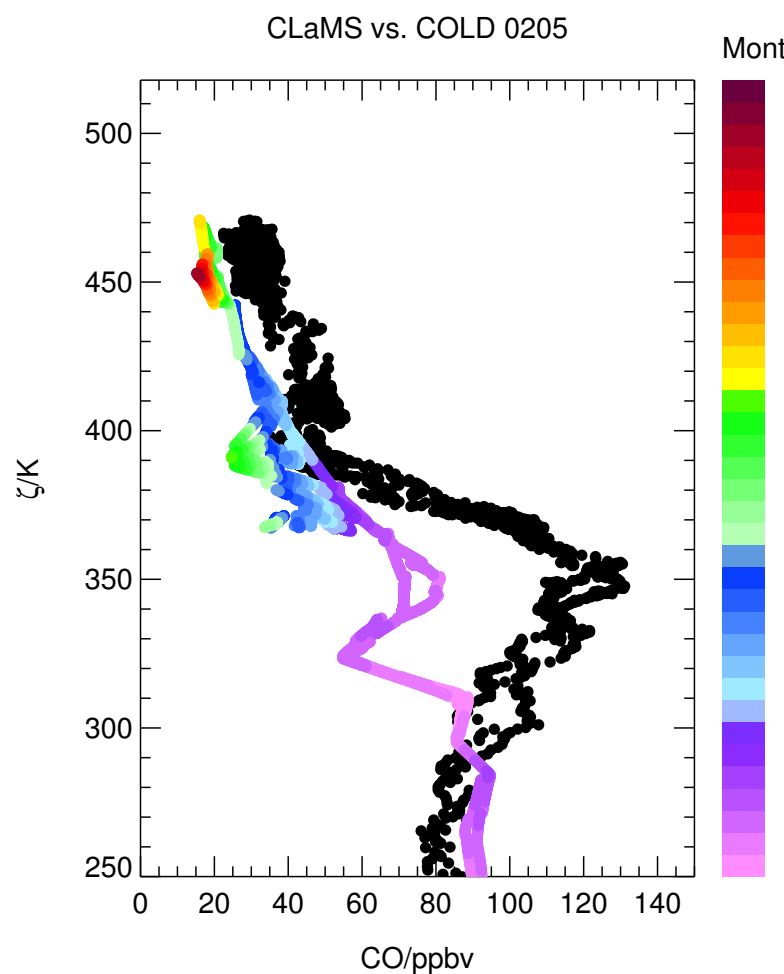

GMDD

4, 1185-1211, 2011

34.

32.

30.

28.

26.

24.

22.

20.

18.

16.

14.

12.

10.

8.

6.

4.

2.

0.

Fig. 5. Comparison of the simulation of CO from CLaMS (coloured) with in-situ measurements from the COLD instrument (black) on the Geophysica on 5 February 2005. During this flight events of fast high-reaching convection were observed. The $x$-axis shows the volume mixing ratio of $\mathrm{CO}$ in ppbv, the $\mathrm{y}$-axis reflects the height using the height coordinate in the model. The mean age of air calculated by the model is colour-coded and given in months.

$\mathrm{CO}$ as a tracer in CLaMS

R. Pommrich et al.

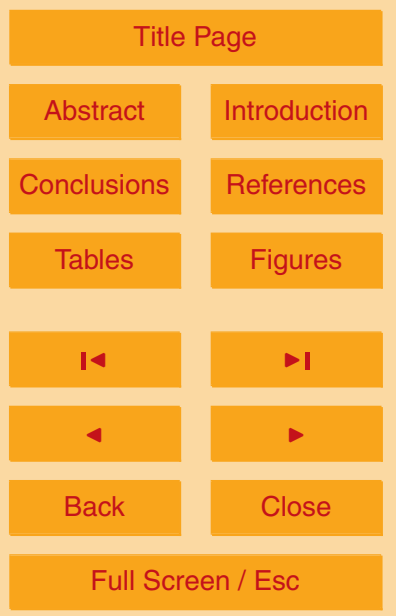

Printer-friendly Version

Interactive Discussion 


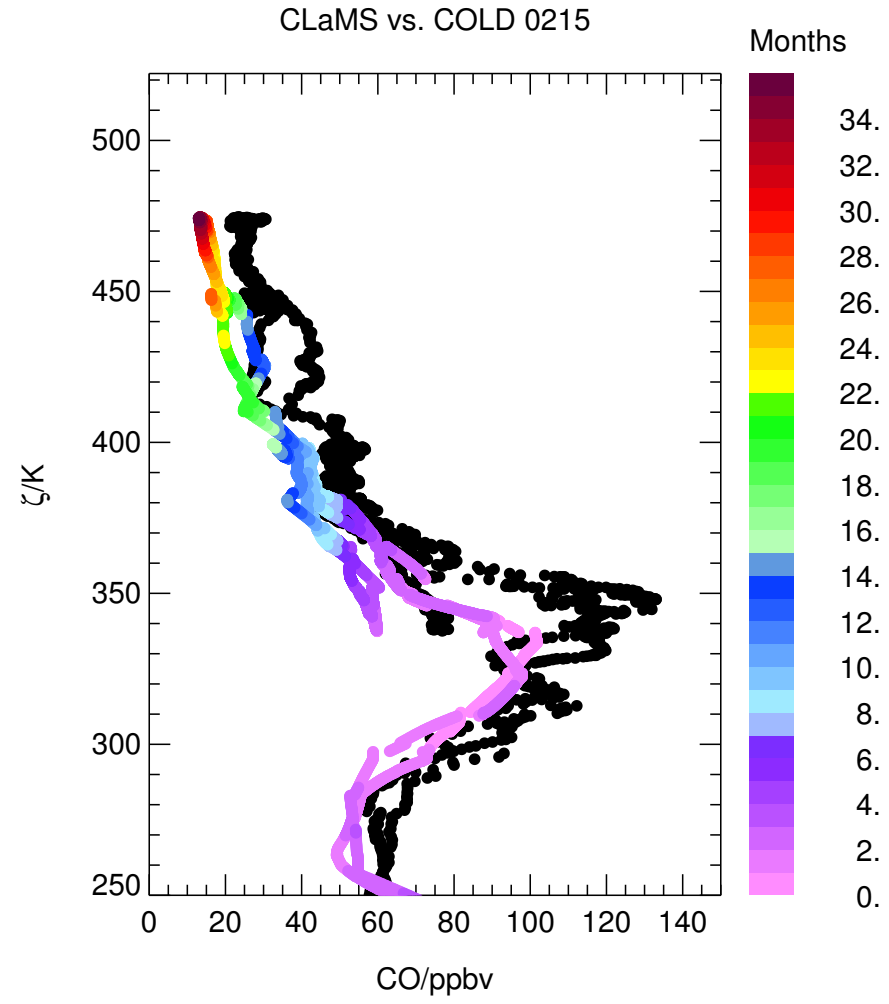

Fig. 6. As Fig. 5, but for 15 February 2005. This flight was planned as a survey flight to measure TTL conditions at background conditions.

\section{GMDD}

$4,1185-1211,2011$

CO as a tracer in CLaMS

R. Pommrich et al.

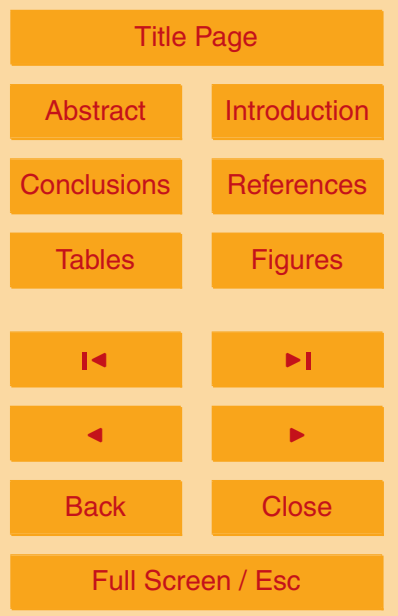

Printer-friendly Version

Interactive Discussion 